\title{
Collusie tussen overheid en bedrijf : een vergeten hoofdstuk uit de organisatiecriminologie
}

Citation for published version (APA):

van den Heuvel, G. A. A. J. (1998). Collusie tussen overheid en bedrijf : een vergeten hoofdstuk uit de organisatiecriminologie. Universiteit Maastricht, Department of Criminal Law and Criminology. https://doi.org/10.26481/spe.19980123gh

Document status and date:

Published: 23/01/1998

DOI:

10.26481/spe.19980123gh

Document Version:

Publisher's PDF, also known as Version of record

\section{Please check the document version of this publication:}

- A submitted manuscript is the version of the article upon submission and before peer-review. There can be important differences between the submitted version and the official published version of record.

People interested in the research are advised to contact the author for the final version of the publication, or visit the DOI to the publisher's website.

- The final author version and the galley proof are versions of the publication after peer review.

- The final published version features the final layout of the paper including the volume, issue and page numbers.

Link to publication

\footnotetext{
General rights rights.

- You may freely distribute the URL identifying the publication in the public portal. please follow below link for the End User Agreement:

www.umlib.nl/taverne-license

Take down policy

If you believe that this document breaches copyright please contact us at:

repository@maastrichtuniversity.nl

providing details and we will investigate your claim.
}

Copyright and moral rights for the publications made accessible in the public portal are retained by the authors and/or other copyright owners and it is a condition of accessing publications that users recognise and abide by the legal requirements associated with these

- Users may download and print one copy of any publication from the public portal for the purpose of private study or research.

- You may not further distribute the material or use it for any profit-making activity or commercial gain

If the publication is distributed under the terms of Article $25 \mathrm{fa}$ of the Dutch Copyright Act, indicated by the "Taverne" license above, 


\section{Collusie tussen Overheid en Bedrijf}

- een vergeten hoofdstuk uit de organisatiecriminologie -

Rede

uitgesproken bij de aanvaarding van het ambt van

hoogleraar in de Criminologie aan de

Universiteit M aastricht op

vrijdag 23 januari 1998

door

Dr. G.A.A.J , van den Heuvel 
Ter herinnering aan A.A.G. Peters 
Vijftig jaar na de oorlog bekende de centrale bank van Zwitserland dat men de rest van de wereld steeds wat had voorgelogen over de afhandeling van het Joodse goud dat de Duitsers daar gestald hadden. Al die tijd moest men het geheim afgeschermd houden. Al eerder had men schoorvoetend toegegeven dat men waarschijnlijk veel crimineel geld in huis had en was men begonnen iets van het bankgeheim los te laten bij kleine rechtshulpverzoeken inzake evident criminele zaken ${ }^{1}$.

Deze langdurige heling is een voorbeeld van collusie, in dit geval tussen de zwitserse bancaire autoriteit en het particuliere bankwezen. Collusie is een ander woord voor heimelijke verstandhouding, met name om illegale praktijken toe te dekken. Collusie kan tussen allerlei partijen voorkomen. Ik beperk me hier tot de samenspanning tussen overheid en bedrijf, of tussen overheidsdiensten onderling. Het gaat me om die medebetrokken overheid.

W ij kennen de overheid als boevenvanger, niet als boef. Ja, er gaat hier en daar wel eens iets fout, en in elke mand zit wel een rotte appel. Maar een ministerie dat of een openbare dienst die crimineel samenspant, valt buiten de verbeelding, ook in criminologisch opzicht. $V$ andaar dat ik spreek van een vergeten hoofdstuk. Want het komt wel voor.

\section{Organisatiecriminaliteit}

Overtredende overheden zijn een vorm van organisatiecriminaliteit. Organisatiecriminaliteit wordt vaak vergeten als men spreekt over dé criminaliteit. Criminologisch is dat ten onrechte ${ }^{2}$.

De wereld van de organisaties is criminologisch even groot en belangrijk als die van de natuurlijke personen, én vanwege hun macht, én vanwege de potentiële schade én vanwege hun omvang, hun kwantiteit. Inderdaad zijn er grote verschillen met natuurlijke personen. Organisaties kunnen grilliger zijn dan mensen, zij kunnen gemakkelijker van karakter veranderen, ze kunnen veel ouder worden en zijn meestal rijker en machtiger dan natuurlijke personen. De wereld van de organisaties kent eigen spelregels en controle instanties, maar dat maakt hun overtredingen niet

1. Queloz (1996), Borghi en M eyer-Bisch (1995).

2. Clarke (1990), van de Bunt (1992), Tonry en Reiss (1993), N elken (1994). 
minder belangrijk voor de criminologie $e^{3}$. Hooguit kan men zeggen dat het tot een andere en deels eigensoortige criminologie leidt die men aanduidt als organisatiecriminologie.

Ook kwantitatief moet men de organisatiecriminaliteit niet onderschatten. Nederland kent 1,2 miljoen erkende organisaties ${ }^{4}$. De helft daarvan bestaat louter uit vermogen en een bestuur, in de andere helft zitten meerdere werknemers. Die organisaties en hun werknemers en besturen kunnen allemaal dader of medepleger zijn aan organisatiecriminaliteit. V oeg daarbij het gegeven dat organisaties vaak door meer regel $s^{5}$ gereguleerd worden dan natuurlijke personen en men heeft een potentiële criminaliteitsmarkt die in elk geval kwantitatief niet onder doet voor de markt van mannelijke jong volwassenen die de commune criminaliteit domineert.

$M$ en staat nu wel te kijken van zo' $n$ beursfraude zaak, maar eigenlijk is het - gezien de omvang van het veld - verbazingwekkender dat er niet veel eerder en veel vaker van die grote zaken zijn. Eén verklaring daarvoor schuilt in de aard van organisatiecriminaliteit. Dat betreft veelal schending van in eerste instantie niet strafrechtelijke regels, gecontroleerd door anderen dan de politie. Die controle organen hebben minder de neiging geconstateerde fouten naar buiten te brengen, ook niet bij grotere zaken. Bijvoorbeeld: niet de FIOD maar de belastinginspecteur behandelt $99 \%$ van de belastingcriminaliteit ${ }^{6}$; een niet onbelangrijkdeel daarvan betreft bedrijven en ondernemingen. Hebt $U$ mevrouw Sorgdrager daar wel eens over horen spreken als ze het had over dé criminaliteit in N ederland?

Organisatiecriminaliteit wordt voor het merendeel behandeld door administratiefrechtelijke instanties. Omdat het gaat om andersoortige daders, regels, controle instanties en sancties wijkt het organisatiecriminologische onderzoek ook nogal af van het klassiek criminologisch onderzoek naar commune delicten waar natuurlijke personen de hoofdrol vervullen. In de organisatiecriminologie vervullen natuurlijke

3. Organisatiecriminologen duiden hun specialistisch veld vaak antagonistisch aan tegenover het veld van de klassieke commune delicten. Zij spreken bijvoorbeeld van 'witte boorden' versus 'blauwe boorden' (Sutherland, 1983); van 'armchair crimes' versus 'street crimes' of van dé criminaliteit tussen 9 en 5 en die van tussen 5 en 9 (Box, 1989); of van 'the crimes of the powerless based on needs' die staan tegenover 'the crimes of the powerfull based on greed', waarmee ook iets gezegd is over het mogelijk motivationele onderscheid tussen de veel voorkomende commune criminaliteit en organisatiecriminaliteit (Braithwaite, 1978).

4. Huisman en Niemeijer m. m.v. Jansen en Braun (1998) hfd. 1.

5. Braithwaite 1989, pp. 40-41.

6. Volgens het convenant (1993) tussen fiscus en OM kan jaarlijks slechts een beperkt aantal zwaardere zaken aangeleverd worden. De laatste paar jaar ligt dat aantal rond de 450. De ernst wordt bepaald via een puntenschaal (On a Swie, 1995). 
personen meestal een bijrol en die bijrol is bovendien door hun functie in de organisatie bepaald.

Ter voorkoming van misverstand; georganiseerde misdaad is iets anders. Dat betreft commune criminaliteit waar de politie exclusief op jaagt. Die is sneller geneigd criminaliteit van groepen als criminele organisatie aan te duiden, zoals we ook weer zagen bij de beursfraudezaak. Het gaat de politie (en het OM) dan toch in de eerste plaats om natuurlijke personen, terwijl organisatiecriminologisch eerder die commissionairshuizen en de criminogene functies van de beurs als markt voorop staan, en niet de individuen?

Waar de criminologie bij commune delicten onderscheid maakt in soorten daders maakt men binnen de organisatiecriminologie onderscheid in soorten bedrijven, soorten markten en soorten dienstverlening. Die gescheidenheid van markten en diensten is op haar beurt weer gekoppeld aan onderscheiden regelgevings-, vergunningverlenings-, controle- en handhavingsinstanties. V roeger bemoeide de overheid zich maar zeer beperkt met het sturen van de private sector, tegenwoordig vindt zij daarin een hoofdtaak. De sociaal economische regelgeving is complex geworden en verandert veel vaker en sneller dan de gedragsregels uit het klassieke strafrecht.

$D$ at is één van de redenen waarom er binnen de organisatiecriminologie extra aandacht is voor de overheid. Een andere reden is dat de overheid zich veel responsiever opstelt ten aanzien van organisaties in vergelijking met natuurlijke personen. Organisaties worden meer betrokken bij bestuur en beleid dat hen betreft. De overheid toont naar organisaties toe meer bereidheid tot toegeven zelf ook fouten te kunnen maken. Zo heeft in ons land de overheid bij monde van wijlen minister $D$ ales ${ }^{8}$ zelf het onderwerp overheidscriminaliteit zeer breed op de agenda gezet. Een uitnodiging waar ik graag op in wil gaan.

\section{Overheidscriminaliteit}

Overheidscriminaliteit is historisch gezien een heel oud en normaal fenomeen. De

7. Niet iedereen deelt deze mening. Hirshi en Gottfredson (1978) pleiten ervoor om ook bij organisaties te zoeken naar verantwoordelijke natuurlijk personen binnen een sociaal psychologische machtsconfiguratie, omdat alleen daar emoties en motieven traceerbaar zijn. A nderen (Coleman, 1985; Shapiro, 1990; Steffensmeier, 1989) betwisten dit ten dele. Ook binnen een juridische machtsconfiguratie en zonder op zoek te gaan naar de feitelijke leidinggever of verantwoordelijke kunnen motieven getraceerd worden.

8. Op het congres van de $V$ ereniging van N ederlandse Gemeenten 2/3 juni 1992, A peldoorn (Huberts, 1994, pp. 7-13). 
bijbel, de koran en veel sprookjes, sagen en mythen gaan daarover. Zo jong als de rechtsstaat is, zo oud is het beeld van de overheid als vijand van het volk. Daar valt veel meer over te zeggen maar dat zal ik nu niet doen. Ook de jonge criminologie van de Italiaanse en Franse school van rond 1900 plaatste de overheid bij voortduring in de beklaagdenbank als dader of mededader. Ook dat thema laat ik hier rusten, net als de gruweldaden die de geschiedenisboeken over de 20e eeuw aan overheden toeschrijven. Ik begin ordinair bij vandaag, met een definitie.

Overheidscriminaliteit betreft delicten, gepleegd door overheidsorganisaties als zodanig, of individuen of groepen daarbinnen, binnen het kader van hun gewone ambtelijk organisatorische functies'. In het engels spreekt men van 'official devian$\mathrm{ce}^{10}{ }^{10}$, 'state crime' ${ }^{11}$ of 'governmental crimes' ${ }^{12}$. In Nederland is bij bestuurskundigen de term 'machtsbederf' in zwang. Huberts ${ }^{13}$ onderscheidt

machtsbederf in bestuurlijke criminaliteit en wettig machtsbederf waarbij de term 'wettig' een wat dubieus adjectief wordt. Om die reden spreken $V$ an Vugt en Boet van formeel en informeel genormeerd niet integer handelen ${ }^{14}$. Men wil met dat 'informele' aangeven dat ook al is formeel de wet niet overtreden, er toch veel mis kan zijn bij een overheidsorganisatie; bijvoorbeeld omdat men burgers als klanten onheus bejegent of omdat men niet doet waarvoor men is ingehuurd. Zelfs het onvoldoende investeren in de kwaliteit van de organisatie valt volgens hen onder deze categorie.

Zo ver wil ik niet gaan. $M$ et $V$ an de Bunt beperk ik het veld tot het formeel genormeerde. Dat veld kan men onderverdelen in drie categorieën: de fouten, corruptie en collusie.

De meerderheid van de rechtsschendingen door overheidsorganen in ons land betreffen gewone fouten. De meeste fouten zijn culpeus, niet ernstig en herstelbaar.

9. Dit is een aangepaste invulling van $V$ an de Bunt's definitie. Hij sprak van groepen in plaats van organisaties en van misdrijven in plaats van delicten ( $V$ an de Bunt, 1992, p. 6). Hoefnagels spreekt van 'institutionele criminaliteit'. "K enmerken van institutionele criminaliteit zijn:

1. overtreding van wetten (of ook wel van wenselijke wetgeving);

2. door overheidsfunctionarissen;

3. in de sfeer van hun functie;

4. met voorbijgaan van de schade aan de burgers;

5. met versterking of uitbreiding van eigen machtspositie of prestige."

(H oefnagels, 1981, p. 25).

10. Douglas en Johnson (1977).

11. N elken en Levi (1996).

12. Ermann en Lundman (1996).

13. Huberts (1992) p. 7; (1994) p. 2.

14. Van Vugt en Boet, 1994, p. 24. 
M en kan zich afvragen of hier de term criminaliteit wel gepast is? Ik zou zeggen van niet, alhoewel de overheid zelf met haar begrip 'kleine of veel voorkomende criminaliteit' de criminaliteitscircel naar de burgers toe wel erg fors heeft uitgebreid. De hinkelparken uit mijn jeugd heten nu vandalisme, rijp voor een $\mathrm{Halt}$ afdoening ${ }^{15}$. Dat vraagt bijna om met gelijke strengheid naar die overheid te kijken. lets anders is het dat de meeste specifieke regels voor overheden geen directe sanktiedreiging kennen maar een indirecte. De grenzen van het juridische sanktiebegrip $^{16}$ worden met de dag vager. De meeste sankties worden bovendien allang niet meer door rechterlijke instanties opgelegd.

Dus als men al van criminaliteit wil spreken dan gaat het hier om veel voorkomende overheidscrimininaliteit. I $k$ wil daar niet nader op in gaan. Dat laat ik graag over aan de makers van "Ook dat nog".

De twee andere categorieën zijn specifieker.

Corruptie betekent letterlijk "bederf". Juridisch kan men haar omschrijven als het misbruik maken van een ambtelijke of politieke positie ten behoeve van zichzelf of een derde ${ }^{17}$. Dit misbruik dient in strijd met de wet of de heersende regels ${ }^{18}$ te zijn, een delict waarvan het bewijs vaak lastig te leveren is.

Collusie omschreef ik al in mijn opening: "heimelijke verstandhouding, met name om het opsporen van strafbare feiten te belemmeren". Als tweede betekenis noemt $\checkmark$ an $D$ ale de "onderlinge samenspanning tussen ambtenaren om ambtsdelicten te plegen".

Theoretisch kan collusie dus ook slaan op een heimelijke verstandhouding tussen bedrijven onderling. Dat laatste wordt echter bij voorkeur aangeduid als kartel, oneerlijke mededinging ${ }^{19}$. Is de overheid erbij betrokken dan resteert de term collusie. Als ik in mijn verdere betoog over collusie spreek, heb ik alleen die variaties op het oog.

15. Een extreem voorbeeld van hoever de grenzen bij de commune criminaliteit vandaag de dag in de praktijk kunnen liggen trof ik aan in de Volkskrant (6.11.' 97):

Een agent in Huissen betrapte Ramona van Spee (13, mavo-scholiere) op het weggooien van een snoeppapiertje. Het kwam haar op vier uur werkstraf te staan; de politie beschouwde haar daad als een 'veel voorkomend delict'.(..). De voorlichter van de politie lichtte toe: "Om te voorkomen dat ze in het justitiële circuit belandde, is het voorval doorgespeeld aan het Halt - bureau".

16. M ulder (1949), Hulsman (1965), Duk (1973), Bolt en Lensing (1993), Vervaele (1994).

17. Ruimschotel (1996).

18 Bijvoorbeeld, op reclamegebied zijn de regels wat niet toegestane reclame is, door de branche zelf uitgewerkt, overigens wel op verzoek van de overheid. D eze zelfregulering heeft een directe publiekrechtelijke werking.

19. Dat oneerlijke kan slaan op allerlei wetsovertredingen. Niemeyer, Huisman, Jansen en Braun (1998) Hfd. 3. 
Heimelijke verstandhouding is overigens niet verboden. Ook hier geldt dat het pas een delict wordt waar het recht wordt geschonden; waar wetten worden overtreden.

E en officier van justitie die illegale opsporingsmethoden van een IRT team door de vingers ziet pleegt collesie; de verzekeringskamer die foute rapportage en te kort schietende dekkingen van verzekeringsbedrijven door de vingers ziet pleegt collusie; een college van $B \& W$ dat heimelijk plaatselijke aannemers structureel bevoordeelt pleegt collusie net als een notaris die zonder dat het opvalt met één bank substantiëel meer en vooral omvangrijkere zaken doet dan met de andere plaatselijke banken. De politie die een oud-chef - nu in dienst van een particuliere beveiligingsorganisatie - van vertrouwelijke informatie voorziet, pleegt collusie; ook als dat gebeurt tijdens een rotarieavondje.

Collusie is binnen het veld van de organisatiecriminaliteit een even vage grootheid als corruptie. Er zijn meer overeenkomsten. Beide zijn geen wettelijke term maar vormen wel erg 'inclusieve' begrippen. Ik bedoel daarmee: er is een sfeer omheen die vaag is, maar het kerndelict is wel moreel heel duidelijk ${ }^{20}$; beiden staan voor een vermoede pathologie van goede samenwerking op de grens van publiek/privaat $^{21}$; beide zijn typische 'afglij' delicten en beide trachten ontdekking van het illegale aspect te voorkomen. Bij beide ziet men bovendien, bij ontdekking, ook dezelfde soort neutralisatietechnieken ${ }^{22}$ (ontkenning, 'blaming the whistle-blower', 'blaming the messenger' ${ }^{23}$ ).

$D$ an het onderscheid: corruptie omschreef ik als het misbruik maken op individueel niveau van de eigen positie ten behoeve van zichzelf of een derde, zonder dat de relevante regels in acht genomen waren ${ }^{24}$. Ruimschotel noemt als diepste wezenskenmerk van corruptie dat men verraad pleegt aan de eigen organisati $e^{25}$.

Collusie lijkt de institutionele variant hiervan. Zij betreft het illegaal gedrag van overheidsorganen ten behoeve van zichzelf én derden. Haar wezenskenmerk is

20. V ahlenkamp en Knauss (1995).

21. Rose-Ackerman (1996), Heidenheimer e.a. (1989).

22. Savona (1995).

23. Voor een klassiek maar nog steeds actueel overzicht naar neutralisatietechnieken, zie Sykes en M atza (1957).

24. Juridisch spreekt men van omkoping. Art. $177 \mathrm{WvSr}$ stelt de actieve omkoping strafbaar, art 328 ter, 362 en 363 WvSr het omgekocht worden van ambtenaren en daarmee gelijkgestelde personen. Dit alles uiteraard inclusief de poging of uitlokking daartoe. In de praktijk gebruikt men meestal art. $225 \mathrm{WvSr}$, valsheid in geschrifte als kapstokartikel om overheidscorruptie aan te pakken (V an de Bunt, 1993).

25. Ruimschotel (1993). 
echter niet zozeer verraad - zondigen tegen de moraal van de club - maar veel meer partijdigheid. Het gaat om een institutioneel legale samenwerking tussen overheden onderling of overheid en bedrijfsleven, die voor legale doelen tot illegale middelen vervalt, en dat verheimelijkt. Dat is meteen het verschil met gedogen, wat niet heimelijk gebeurt.

A nders gezegd, collusie waar de overheid bij betrokken is betreft altijd heimelijk gedogen met potentieel ernstige gevolgen. Dit lijkt specifiek, maar dat gedogen kan op allerlei mogelijke illegale praktijken slaan, zowel formeel als materieel rechtelijk en heeft vrijwel altijd een structureel karakter.

Waar politiek en bestuur bij herhaling aandacht vragen voor het corruptieprobleem met zijn sterk persoonlijk individueel accent, wil ik aandacht vragen voor het collusieprobleem met zijn struktureel organisatorisch accent.

$N$ ederland is geen typisch corruptieland ${ }^{26}$. Corruptie gedijt met name in zwakke en niet-democratieën, staten waar politieke macht te koop is. Corruptie als private verrijking vraagt een gesloten infrastructuur, vraagt foute voorbeelden aan de top en liefst onderbetaalde ambtenaren ${ }^{27}$. Nederland is een open democratie met goed betaalde ambtenaren en integere leiders. De financiering en de toegang tot de media is voor onze politieke partijen goed geregeld en wordt behoorlijk gecontroleerd. Wij zijn geen corruptieland, wel een collusieland.

In het navolgende wil ik dat toelichten en kijken naar een aantal vormen van overheidscollusie die ik theoretisch wil duiden. Het is een vergeten categorie in de criminologie, dus ik zal soms wat leentjebuur spelen bij andere disciplines. Ik zal afsluiten met enkele opmerkingen ter preventie en de rol van het criminologisch onderzoek daarbij.

\section{Collusieblootleggers}

Collusie blijkt vrijwel altijd pas achteraf, als het kalf verdronken is en men bezig is met het dempen van de put. Eén van de belangrijkste blootleggers vormen parlementaire onderzoeken en enquêtes.

- Bij de RSV enquête bleek dat mijnheer Molkenboer twee petten op had (directeur generaal op het ministerie van economische zaken en regeringswaarnemer in het bestuur van RSV). Die overheidsbemoeienis had uiteindelijk geleid tot

26. Transparancy International rekent ons land tot de minst corruptiegevoelige naties van de wereld (NRC 17.03.96).

27. Clarke (1983), Heidenheimer (1989), Van den Heuvel (1994), Nelken en Levi (1996). 
2,2 miljard subsidie, waarna het bedrijf toch failliet ging. Eigen recht maakte Molkenboer toen hij toestond dat WIR premies verstrekt mochten worden aan RSV voor de bouw van schepen waar helemaal geen opdracht voor bestond. L ater sprak de onderzoekscommissie van een geschuif met geld, bevoegdheden en verantwoordelijkheden "met een overgave die aan de speeltafel niet zou hebben misstaan" 28

- Bij de WAO casus, die door de Commissie Buurmeijer is onderzocht bleek dat én de sociale partners én de overheid wisten dat de wet lange tijd misbruikt werd. Een wet die bedoeld was voor de ongeveer 200.000 arbeidsongeschikten, maar waar 'we' 900.000 mensen oneigenlijk in geparkeerd hadden alvorens in te grijpen en waar anno '97 nog 800.000 mensen inzitten, ondanks herkeuringen etc. Tot 2010 blijven we jaarlijks miljarden afbetalen op die post ${ }^{29}$.

- De visserij enquête liet zien hoe het Ministerie van Landbouw en Visserij wetsontduiking uitlokte. Het idee om boven-quota bevissing witvis te noemen, een categorie die Brussel niet kende, kwam volgens velen van het ministerie zelf. De schade van die overbevissing is onberekenbaar maar dat er toen veel crimineel geld verdiend is, oogluikend toegestaan door de overheid, staat buiten $\mathrm{kijf}^{30}$.

- De Walrus affaire ging om een budgetoverschreiding van 'slechts' enkele honderden miljoenen zonder dat de kamer er van afwist. Ook hier ging het geleidelijk. De bouw was vertraagd, nieuwere wapens en instrumenten waren op de markt gekomen. "Bevriende" industrieën boden aanpassingen aan. De ambtenaren van defensie voelden zich ook hier meer adviseur van de generaals dan controleurs van de bouwers ${ }^{31}$.

- De enquête bouwsubsidies betrof illegaal verstrekte bouwsubsidies aan het $A B P$. Daar was men vrij snel achter op provinciaal niveau, alleen het ministerie ontkende glashard dat er iets mis was en verdedigde lange tijd het $A \mathrm{BP}^{32}$.

Parlementaire enquêtes zijn collusie-blootleggers bij uitstek met name omdat men

28. RSV enquêteverslag, Handelingen Tweede Kamer 1984/85 p. 455.

29. Hibbeln en Velema (1993).

30. Vervaele, Ruimschotel en Widdershoven (1990), Tuurenhout (1992). Voor EC fraude in het algemeen zie Tutt (1990), Passas en N elken (1993).

31. Wassenberg (1987).

32. Tuurenhout (1992). 
zich richt op netwerken en processen en niet specifiek zoekt naar schuldige personen, al hebben rond deze enquêtes meestal wel bewindspersonen hun consequenties moeten trekken.

De niet-aansprakelijke (top)ambtenaren vormen een afzonderlijk probleem bij collusie. Zij blijven meestal zitten na een schandaal, terwijl zij soms meer dan de verantwoordelijke politici hebben bijgedragen aan het afglijden richting collusie $e^{33}$.

V oorafgaand en naast die enquêtes dient de journalistiek genoemd te worden als collusieblootleggers. De meeste enquêtes vinden hun oorsprong in alarmerende mediaberichten waar kamerleden dan weer vragen over stellen zodat 'balletjes gaan rollen'. De democratische controlefunctie van de onderzoeksjournalistiek kan juist ten aanzien van het blootleggen van collusiepraktijken niet genoeg onderstreept worden. Dat die onderzoeksjournalistiek het mede moet hebben van 'lekken en lekkers' neem ik daarbij graag voor lief. $M$ et Beenakkers en Grapendaal meen ik dat de schade van lekken in dit soort zaken meestal minder is dan de schade van overheidscriminaliteit die afgedekt blijf ${ }^{34}$.

Bij de officiële professionele 'public interest' controleurs, de notarissen en de accountants, past - omgekeerd - juist bescheidenheid. Zij zijn eerder zelf collusionist dan dat men collusie naar buiten brengt en aankaart. Dat komt mede - wat gechargeerd uitgedrukt - omdat men dienstverlening vaak voor controle stelt. Pro forma beweren beide beroepsgroepen het tegendeel, maar de facto is men de gevangene van het eigen (meestal zeer goede) inkomen. De notaris of accountant die bij controle op fraude binnen het bedrijf stuit, zal deze niet melden bij de overheid, maar bij het bestuur - zijn opdrachtgever - en zal correctie vragen, conform de beste tradities van coöperatieve controle.

\section{Schade}

Zoals bij veel organisatiecriminaliteit lijken op het eerste gezicht de slachtoffers van collusie afwezig; maar dat is slechts schijn. Het belangrijkste slachtoffer heet de publieke zaak. Dat kan slaan op heel ideëel de kwaliteit van de democratie en het vertrouwen van burgers in bestuur, tot heel 'down to earth' gemeenschapsgeld dat misbruikt is of oneerlijk verdeeld cq. de belastingbetale ${ }^{35}$.

33. Bovens (1990), Tuurenhout (1992).

34. Beenakkers en Grapendaal (1995).

35. Hierachter ligt de schijnbare tautologie dat het belangrijkste slachtsoffer van overheidscriminaliteit de overheid is. De Hoge Raad vondt dat niet zo 'schijnbaar' en baseerde mede daarop haar beruchte $\mathrm{V}$ olkel en Pikmeer arresten. H et ministerie werkt 
Burgers en bedrijven kunnen direct gedupeerd worden. Collusie in bijvoorbeeld de gezondheidszorg of in de farmaceutische industrie ${ }^{36}$ bedreigt direct de gezondheid van burgers. Collusie tussen onderwijsinspectie en scholen kan de kwaliteit van het onderwijs aantasten. Collusie tussen overheid en bedrijven kan marktverhoudingen en vrije mededinging verstoren of het milieu verpesten.

E en gevolg van succesvolle collusie kan zijn het ontstaan van collusie bij ook andere overheidsdiensten. Dit epidemisch effect treedt op bij veel vormen van organisatiecriminaliteit onder het motto: wat andere organisaties blijkbaar mogen, mogen wij $00 k^{37}$.

Collusie kan, als het veel voorkomt en nooit aan de kaak wordt gesteld, corruptie bij politici of ambtenaren uitlokken en zo de rechtsstatelijkheid van bestuur fundamenteel aantasten ${ }^{38}$.

Dat speelde in Italië, al hoeven we niet zo ver te gaan. Dohmen schetst in zijn onderscheiden boek De V riendenrepubliek de Limburgse corruptieschandalen ook tegen een achtergrond van ten minste collusie-achtige praktijken ${ }^{39}$. Collusie fungeert dan als legitimatie voor persoonlijke corruptie.

Collusie kan ook leiden tot politieke apathie. Als burgers zien dat overheden zich boven de wet stellen, tast dat het vertrouwen in, en de geloofwaardigheid van diezelfde overheid aan. $V$ olgens $V$ an $W$ olferen was daarvan sprake in het Japan van de jaren ' 70 en ' $80^{40}$.

\section{Vergeten hoofdstukken}

Vrijwel alle illegale praktijken binnen onze sponzige overlegorde die enquêtes boven tafel brengen worden in ons land niet als criminaliteit benoemd. M en be-

nu aan een voorstel dat deze hond weer wel in zijn eigen staart kan en mag bijten.

36. Braithwaite (1984).

37. Clinard en Y eager (1980), Levi (1991), Stanley (1992).

38. In het Italië van A ndreotti en zijn voorgangers mocht te veel te stiekem. De systemen van cliëntalisme, brokerage en patronage - Italiaanse varianten van corrumperende collusie - waren zo succesvol dat zelfs de Siciliaanse maffia en de gamorra van $\mathrm{N}$ apels mochten meedoen en invloed kregen op het legitieme bestuur. Daarom was de campagne "schone handen", die zich officiëel alleen op individuele corruptie richtte, zo rechtsstatelijk van pretentie en leidde vrijwel onmiddellijk tot een compleet nieuw landschap van politieke partijen. N elken (1996), N elken en Levy (1996), Pizzorno en Della Porta (1996).

39. Dohmen (1996).

40. Van W olferen (1989). Zie ook W oodall (1996) en M itchell (1996). 
schouwt het als de rekbare grenzen tussen formele wetten en een informele wetshantering die 'in de toekomst' beter moet. Ook als er veel geld mee gemoeid is noemen we het erg, maar geen criminaliteit.

W aarom durven A merikanen of A ustraliërs bij structureel bestuurlijke criminaliteit wel van 'gouvernmental crimes' te spreken, en wij niet? Het antwoord dat ik in het begin gaf, omdat er geen politie en $\mathrm{OM}$ aan te pas komt, legt de definitiemacht helemaal bij de overheid zelf. En die is terughoudend. Een onderzoek uit 1995 naar 0 vertredende overheden in milieuzaken, kwam over drie jaar tot 56 zaken, waarvan er 26 zijn geseponeerd, 27 getransigeerd (gemiddeld transactiebedrag fl. 5200,-) en maar bij twee kon of wilde men dagvaarden. De ene leidde tot een boete van fl. 2250,- en de andere zaak mondde uit in het beroemde $V$ olkel arrest, de officier werd niet ontvankelijk verklaard.

Kortom, de overheid heeft dominante benoemingsmacht en gaat daar - als het collega overheden betreft - zuinig en selectief mee $\mathrm{om}^{41}$.

Kees en Chrisje Brants behandelen dit benoemingsprobleem in hun proefschrift ${ }^{42}$ ten aanzien van fraude door bedrijven gepleegd. Dat was aanvankelijk ook een 'non issue' die buiten het criminaliteitsbegrip viel. $M$ aar vanaf eind jaren zeventig veranderde dat, met name omdat de media en politie en OM er meer werk van maakten. $M$ et de komst van de persofficier en de fraudeofficier kreeg het delict als categorie meer status en aandacht. $V$ anaf 1984 is het zelfs opgenomen in de CBS statistiek. $M$ aar deze statistiek beperkt zich louter tot politiecijfers. De fraudes door bijvoorbeeld de fiscus of sociale diensten zelf afgehandeld vallen erbuiten hoewel het daar soms om veel grotere bedragen gaat. $H$ et blijft dus wel gaan om selectieve beelden. Hier heeft de criminologie, en de organisatiecriminologie in het bijzonder, een eigen kritische functie: het corrigeren van selectieve beelden, zoals de overheid en de media die presenteren. Die zijn nu te exclusief verbonden met commune delicten, opgespoord en vervolgd door politie en justitie, die vooral individuele aansprakelijkheid zoekt en met collectieve aansprakelijkheid - zo blijkt steeds weer - te weinig kan in de zin van preventieve en creatieve sanctionering.

Ik pleit voor een ruimere en structurelere visie waarbij men inderdaad moeilijk om de rol van de overheid zelf heen kan. Dat motief speelde in elk geval bij mij sterk mee, vandaag over overheidscollusie te praten, als vergeten hoofdstuk.

Ik zie collusie tussen overheid en bedrijven niet als het meest bedreigende criminaliteitsprobleem, in elk geval niet in ons land nu, maar wel als een wezenlijk probleem waar men altijd op verdacht moet zijn met name als men organisatiecriminaliteit analyseert. Achter elk bedrijf zit een overheid die dat bedrijf controleert en

41. Kleiman, $V$ an den Berg en $V$ an der Linden (1995).

42. Brants en Brants (1991). Zie ook M CBarnet, die spreekt van 'the management of stigma' (1991). 
adviseert, lokaal, nationaal en internationaal. Soms is die overheid geprivatiseerd, soms regelt ze via convenanten, soms laat ze de branche zelf de regels maken, maar het blijft een (mede)verantwoordelijkheid waar die overheid zelf op aangesproken kan worden. Dat gebeurt te weinig.

I $k$ heb $U$ tot nu toe een beeld geschetst van het fenomeen. Journalisten en enquêtes leggen het bloot. Andere instanties dekken het af. En de criminologie doet er te weinig mee. $\mathrm{Nu}$ de waarom vraag, de verklaringen, daarna de alternatieven en rol van het onderzoek daarbij.

\section{Over goede samenwerking}

De eerste verklaringsdimensie die ik wil noemen is cultureel-historisch.

In ons land is niet-openbare samenwerking tussen overheid en bedrijfsleven heel gewoon en al heel oud. Allerlei sectoren en branches hebben hun contacten op de vakministeries, waar regulier overleg mee bestaat. Over en weer wisselt men informatie uit. De ambtenaren melden welk beleid er dreigt aan te komen uit zowel Brussel als Den Haag, waarop de organisaties dan kunnen reageren met voor hen optimale aanpassingen; omgekeerd melden de organisaties waar bij hen de knelpunten zitten waarbij de overheid wellicht zou kunnen helpen, en wat men liever zelf wil reguleren dan dat de overheid dat doet of men pleit voor convenanten of kaderwetgeving. M en informeert en adviseert elkaar op basis van wederzijds respect, zo kan men deze praktijk samenvatten, die niet alleen op rijksniveau speelt, maar ook op provinciaal en gemeentelijk niveau.

$V$ eel contactambtenaren ${ }^{43}$ zijn naast adviseur echter ook controleur, het bekende twee petten probleem ${ }^{44}$. Zij rapporteren de minister hoe de sectoren en branches zich houden aan de spelregels die het parlement hen heeft opgelegd. Daar zitten soms inspecties tussen, maar het blijft wel gaan om wat in de vakliteratuur wordt aangeduid als coöperatieve controle: controle op basis van samenwerking tussen controleur en gecontroleerde ${ }^{45}$. De kenmerken van coöpe-ratieve controle zijn (a) egalitaire gezagsverhoudingen; met gaat met elkaar om als gelijken (b) wederzijds vertrouwen vormt de grondslag voor de samenwerking, en (c) als een bedrijf zich niet aan de afspraken kan houden meldt men dit liefst zelf én aan de sector én aan de inspectie. Het streng ingrijpen door de overheid gebeurt maar in laatste instantie,

$43 \mathrm{I}$ bedoel daarmee al die ambtenaren die serieuze onderhandelingsbevoegdheden hebben ten opzichte van het bedrijfsleven.

44. V an den Heuvel (1993), pp. 37 ev.

45. Kagan (1978); Bayley (1979); Bardach en Kagan (1982); Kagan en Scholz (1984); Hawkins (1984); Frank (1984); Pearce en Snider (1995). 
onder het motto: wie niet horen wil moet voelen.

Er zit een uitgebreide normatieve orde achter het coöperatieve controlemodel waar in ons land mee gewerkt wordt bij het reguleren en controleren van het gedrag van organisaties. Het is een goed werkende typisch responsieve orde, die in wezen al honderden jaren bestaat. $V$ an het middeleeuwse gildenwezen, via de VOC en koning-koopman Willem tot aan de uitbouw van de publiekrechtelijke bedrijfsorganisatie van naoorlogs ondernemend $\mathrm{Nederland}^{46}$, het was allemaal met name gestoeld op een ideologie van coöperatie, (neo)corporatistisch samenwerken op basis van wederzijds vertrouwen tussen overheid en bedrijfsleven, of zo men wil de sociale partners ${ }^{47}$. Organen als de SER en de Raad van A rbeid, product- en bedrijfschappen zorgden voor een nauwsluitend netwerk van overleg dat wetgeving en inspectie stuurde. Zij zorgden voor een rustig sociaal economisch klimaat waarin organisaties goed konden gedijen. De geleide loonpolitiek was ook op dit overlegmodel gebaseerd. Hoewel die formeel al decennia afgeschaft heet, werkt die in feite nog door tot de dag van vandaag, tot de dagen van het 'poldermodel'48. Ons land heeft in het buitenland als zodanig een reputatie opgebouw $\mathrm{d}^{49}$. Wij kennen ongewoon weinig sociaal-economische conflicten. Er zijn wel tegenstellingen die aanleiding zijn voor problemen, maar die lossen we liefst binnenskamers op, in goed overleg.

In bestuurskundige literatuur ${ }^{50}$ wordt expliciet gewezen op de risico's van neo corporatisme en horizontaal of onderhandelend bestuur. M en noemt met name zaken als stagnatie in ontwikkeling, ontdemocratisering, het ontstaan van genotuleerde en ongenotuleerde ordes met bijbehorende ineffectiviteit. M en maakt zich zorgen dat de kloof tussen de beleidsrethoriek en beleidspraktijk omwerkbaar groot wordt. $\mathrm{M}$ aar niemand noemt het probleem van het afglijden in illegale praktijken crimineel.

Dit afstandelijk en instrumenteel technisch analyseren ziet men ook bij de discussies over 'de ambtenaar als publiek ondernemer ${ }^{15}$. Dat er meer aan de hand kan zijn met deze zakenman-politicus of ambtenaar, leert het onderzoek van Donatella della

46. V an den Heuvel (1994).

47. Wassenberg (1980).

48. Hooguit kan men spreken van een iets meer op het conflict geörienteerde periode eind jaren zeventig. L ijphart (1968) dacht toen dat hij zijn "politics of accommodation" fundamenteel moest aanpassen. $\mathrm{Nu}$ weer twintig jaar later kan men zeggen dat die periode toch meer een intermezzo was dan een echte wending.

49. Kagan (1990), Gladdish (1991).

50. Stout en Hoekema (1994).

51. Noordegraaf, Ringeling en Zwetsloot (1995). 
Porta ${ }^{52}$. Haar analyse van dit fenomeen accentueert de criminogene risico's van dit nieuwe mengproduct van praktisch bestuur zowel richting individuele corruptie als afhankelijk van de politieke cultuur - richting structurele collusie.

\section{Vertrouwens- en machtstheorie}

Theoretisch is collusie een deviantie van een regulerings- en controlesysteem, dat gebaseerd is op coöperatie, die op zijn beurt weer gebaseerd is op wederzijds vertrouwen. Er zijn soorten vertrouwen. Nelken ${ }^{53}$ stelt systeemvertrouwen en interpersoonlijke vertrouwensnetwerken tegenover elkaar. In culturen waar het systeemvertrouwen laag is (bv. zuid Italië), is men gedwongen meer werk te maken van de interpersoonlijke netwerken, van de "interpersonal trust dimension" als een privaat soort sociaal verzekeringsvangnet.

$\mathrm{H}$ et omgekeerde geldt echter evenzeer. W aar het systeem-vertrouwen redelijk hoog is (bv. Engeland) is de noodzaak tot uitgebreide interpersoonlijke vertrouwensnetwerken minder groot. Een laag systeemvertrouwen zou correleren met een neiging tot corruptie. En culturen met een hoog systeemvertrouwen zouden 'schoner' zijn, in de zin van niet- of minder corrupt.

$\checkmark$ eel systeemvertrouwen lijkt prettig voor een natie. Het geeft een bestuur een hoge mate van legitimiteit en waar het bestuur in de fout gaat lijkt het minder bedreigend, is het meer incidenteel. Daar kan men echter ook anders tegenaan kijken en stellen dat veel systeemvertrouwen burgers onkritisch maakt en aldus uitnodigt tot juist collusie.

E en andere benadering kijkt meer naar de spanning tussen vertrouwen en wantrouwen, psychologisch uitgewerkt door Gamson in zijn klassieke studie Power and Discontent ${ }^{54}$. Dit onderzoek sluit direct aan bij onze twee petten metafoor: adviseur en controleur. Gamsons onderzoek was een pleidooi voor maximalisering van de 'trust-dimension'. Later werkte hij dit model agressiever uit als uiteindelijk een strijd om vertrouwen, en daar weer misbruik van maken: het coöptatie debat ${ }^{55}$.

$\mathrm{Hij}$ is in die zin typisch A merikaans, dat hij niet echt gelooft in een eerlijk twee partijen overleg, in een machtsbalans, in wederzijds vertrouwen alsof het om twee gelijkwaardige fusiepartners gaat. Daarachter ziet hij toch steeds - als 'hidden agenda' - een strijd om de uiteindelijke heerschappij. Coöperatie is voor hem uiteindelijk een slimme vorm van coöptatie, inpakken via overleg of te wel 'capturing'.

52. Della Porta en M ény (1995; 1996) Della Porta (1996).

53. Nelken (1994).

54. Gamson (1968).

55. Gamson (1975). 
Collusie als 'capturing' benadrukt dat de overheid direct afhankelijk is van de economische grootmachten in een land en dat de private kartels het publieke bestuur min of meer hebben overgenomen. Economen als Ayers spreken van volgroeide collusie in grote landen als de VS, Japan en Australië, niet vanwege specifieke casussen betreffende illegale praktijken, maar omdat de industrie de grenzen van de legaliteit volledig in regie heeft ${ }^{56}$.

Kijken we naar onze Nederlandse collusie-voorbeelden dan is daar veel meer sprake van dat de doelen beide overlegpartners meegetrokken hebben naar dat hellend vlak, misschien wel met coöptatieve bijbedoelingen, maar uiteindelijk zat men wel samen als medeplichtigen aan de verkeerde kant van de juridische streep. In A merika liggen die verantwoordelijkheden veel meer gescheiden. Zou het liggen aan typische N ederlandse onderhandelingsstijlen? Is bij ons de vierde macht zo sterk?

Theoretisch geeft Mauk Mulders machtsafstand-reductietheorie hier een mogelijke verklaring ${ }^{57}$. In kleine landen zou de machtsafstand tussen een ministerie en het bedrijfsleven zo klein zijn dat men kan geloven in een machtsbalans. In grote landen weet het ministerie dat men veel minder kan sturen en dat er een veel grotere machtsafstand is ten opzichte van de machtige industriële sector. De legitimiteit van beleid is daardoor minder stuurbaar. Niets voor niets zei Foster ${ }^{58}$ dat zijn president meer te vertellen had over de rest van de wereld dan over Detroit, Chicago, Los Angelos of $\mathrm{N}$ ew $\mathrm{Y}$ ork.

\section{Effecttheorie}

Er bestaat een economie binnen het sociaal economische ordeningsrecht; er zijn belangrijkere en minder belangrijke regels. Als er geschoven wordt richting collusie, zal dat eerder de minder belangrijke regels betreffen, dan de belangrijkere. Daar is ook meer ruimte voor gedogen, dat althans leert de equity-psychologie ${ }^{59}$. $M$ aar wat is belangrijk en onbelangrijk en weten we dat meestal niet pas jaren later? Praten over belangen suggereert inzicht in het effect.

Reisman maakte daarvan gebruik in zijn theori $e^{60}$. Hij ziet regelingen als een mythe systeem. Dat zijn de verhalen rondom een regelsysteem; waarom de regels er zijn, wat de pretenties zijn, en hoe deze regels moeten zorgen dat die pretenties gerealiseerd worden. Mythe systemen zijn idealistisch van karakter, zij communiceren

56. Ayers (1987), A yers en Siegelman (1988).

57. Mulder, (1960; 1977; en 1980).

58. Foster (1966).

59. Walster, Walster en Berscheid (1978).

60. Reisman (1979). 
doel en middelen. $M$ aar in de praktijk zal blijken dat regels maar beperkt worden toegepast. Ze werken op een bepaalde - per definitie - beperktere manier. Dat noemt hij de 'operational code'. Dat is het alledaagse praktijkgezicht van een regeling. Nu kan het zijn dat dat alledaagse gezicht wel erg afwijkt van de oorspronkelijke pretenties, bijvoorbeeld omdat ambtenaren iets heel anders doen dan ze moeten doen. Dat hoeft nog geen collusie te zijn, wat immers een achteraf oordeel is dat rekening houdt met de gronden. $M$ aar als het dat blijkt te zijn is er een probleem. Dat 'blijken' is meestal een kwestie van het publieke debat in gemeenteraad, parlement of in de media. Daar wordt de ergheid van de gebleken collusie gewogen en vooral, daar wordt geanalyseerd hoe het kon gebeuren, waar het aan lag. Afhankelijk daarvan zal ook de reactie zijn op collusie, die kan gaan tussen symbolische kruistocht zonder veel feitelijke veranderingen in beleid en organisatie (symbolische politiek), of een echte inhoudelijke reorganisatie die de in gebreke gebleven dienst wezenlijk zal veranderen, iets wat overigens ook pas na verloop van tijd zal blijken.

Riesman's theorie gaat op voor alle overheidsdevianties, voor fouten, collusie én corruptie. Het is vooral een effect theorie. Het gaat om de gradatie in fouten na het bekend worden (liefst als schandaal) en het reageren daarop op korte en lange termijn.

De RSV enquête was een typische collusiezaak. Die heeft niet geleid tot veel reorganisaties of personeelswisselingen, maar wel tot een grotere terughoudendheid in het steun verlenen aan bedrijven in nood. Het is onbewijsbaar maar waarschijnlijk heeft de RSV zaak veel leergeld opgeleverd voor bijvoorbeeld de afhandeling van de Fokker-casus.

Wij reageren op collusie schandalen verbaal met kruistochten voor minder machtsbederf, maar de echte 'reform' betreft vooral 'lessen voor de portemonnee'.

\section{Organisatiecriminologie}

De klassieke criminologische theorieën zijn erg geënt op traditionele commune criminaliteit en individueel daderschap. Organisaties als dader vallen veelal buiten de criminologische verbeelding, al zijn er uitzonderingen. Zo is er de Australische school rond J ohn Braithwaite ${ }^{61}$. Die heeft serieus werk gemaakt van een structurele benadering van organisatiecriminaliteit ${ }^{62}$, met de nodige aandacht voor de rol van de

61. Fisse en Braithwaite (1983), Braitwaite en Pettit (1990), Gabrosky en Braithwaite (1986), A yers en Braithwaite (1992).

62. Het 'Y ale Researchproject on White Collar Crime' van W eisburd, Reisman, Katz, Reiss, Shapiro, Vaughan en Wheeler is qua omvang en aantal publicaties groter, dan dat van hun A ustralische collegae, maar theoretisch is het minder coherent en ambitieus als 
overheid hierbij. Twee elementen wil ik er hier uitlichten: het begrip 'shaming' en het belang van public interest groups of te wel PIG's.

$M$ et 'shaming' bedoelt hij het moraliserend aan de kaak stellen van fout gedrag zonder uit te sluiten; het is een soort tegengestelde stigmatiseringstheorie ${ }^{63}$. Juist bedrijven zijn erg gevoelig voor hun reputati $e^{64}$. Daar kan men ze raken en beïnvloeden. Dat geldt overigens ook voor overheidsorganisaties. Het strafrechtelijk sanktieapparaat mag disfunctioneel heten voor het sturen van organisatiegedrag, het dreigen met de sterke arm op zich kan reuze effectief zijn. Waar dat preventief werkt is het functioneel. In die zin is Braithwaite ook geen abolitionist. Hij pleit voor werkzaam recht. Dat is met het strafrecht bij commune delicten van natuurlijke personen maar beperkt het geval ${ }^{65}$.

Zijn pleidooi voor PIG's is verbonden aan een pleidooi voor meer 'responsive regulation' dat dicht aanzit tegen onze overlegeconomie, maar waar naast overheid bedrijven en vakorganisaties ook specifieke burgerbelangengroepen kunnen aanslui$\operatorname{ten}^{66}$. Dat lijkt plannenmakerij en bestuur ingewikkelder te maken, maar wat men aan efficiëntie verliest, wint men later aan legitimiteit ${ }^{67}$. Hij waarschuwt expliciet voor het collusiegevaar juist als men PIG's buiten het overleg houdt. Een responsieve rechtsorde dient de direct betrokken belangengroepen bij het overleg te betrekken. Dan stelt men zich controleerbaar op en is het risico op collusie minimaal.

Ons land heeft de nodige ervaring met PIG's als collusiebewakers. M et name in de milieusfeer heeft men sterke posities afgedwongen. Waar Ayers en Braithwaite stelden dat de overheid deze belangengroepen moet uitnodigen om legitimiteitsredenen, is de praktijk in ons land eerder, dat de groepen zelf zo'n status opgebouwd hebben dat de overheid er simpelweg niet meer omheen kan. Greenpeace, Natuur en M ilieu, Reinwater, Stop Uitbreiding Beek tot en met het eerbiedwaardige $N$ atuurmonumenten hebben politieke macht verworven en sturen zo mede de grenzen van onze economische ordening. Of men daarmee ook echt grip heeft op het collusierisico in die milieusfeer blijft de vraag.

In ons land speelt een ideologische discussie rond organisatiecriminaliteit, zonder speciale aandacht voor de rol van de overheid daarbij. Dat betreft de visie van $V$ an

de groep rond Braithwaite ( $\mathrm{Y}$ ale studies on White Collar $\mathrm{C}$ rime funded by the $\mathrm{N}$ ational Institute of J ustice, Part I to IV).

63. Braithwaite (1989) ch. 9.

64. Fisse en Braithwaite (1983).

65. D aarin staat Braithwaite overigens niet alleen. Zie voor overzichten: De Haan (1990); $\checkmark$ an Swaaningen (1996).

66. A yers en Braithwaite (1992) ch. 3.

67. Hoekema en Stout wijzen op dit zelfde punt. Hoekema en Stout (1994). 
de $B$ unt $^{68}$, die gelooft in het opwaarderen van de sociale responsiviteit van bedrijven, en Punch ${ }^{69}$, die daar in hoge mate aan twijfelt. Als ze de kans krijgen en het risico op repressieve reactie gering is zal elk 'gezond' bedrijf de regels overtreden, geobsedeerd als men is door het winstmotief, aldus Punch. Zelf herken ik zowel het optimisme van $V$ an de Bunt, als het pessimisme van Punch, maar wil daar de verwijzing naar die andere partijen, de overheid en de belangengroepen aan toevoegen. Bedrijven zijn geen sociale eilanden.

Punch, bouwt met name voort op het werk van Box en Clarke, en hun accent op het private van het zelfstandig ondernemerschap. De risicodrager kan ook risico's nemen in juridische sferen.

$V$ an de Bunt bouwt voort op het werk van Nonet en Selznick, Stone en Bovens ${ }^{70}$ die benadrukken hoe organisaties in een voortdurende interactie staan met hun omgeving. Die omgeving kan integriteit in bedrijfsbeleid en bestuur oproepen en stimuleren. In potentie wil men best. Dat leest men ook in boeken over bedrijfsethiek ${ }^{71}$. $\mathrm{D}$ at kan kloppen, al mis ik de overheid en is het een alles behalve rustig proces.

De SHV bleef zaken doen met het appartheidsregime van De Clerk en zijn voorgangers, ondanks de wereldwijde oproep tot boycot, die ook door onze regering gesteund werd. Pas na het criminele middel van de $M$ akrobrand in $\mathrm{N}$ uth trok SHV zich terug uit Zuid Afrika, niet om fatsoensredenen, maar uit overmacht.

Hier had niet de overheid maar de PIG succes. Dat was bovendien een criminele groep.

Een positiever en, niet toevallig, recenter voorbeeld:

Shell ging de dialoog aan met haar natuurlijke vijand Greenpeace in zake het laten afzinken van het Brent Sparr platform in de oceaan. Dat was een gebrekkige dialoog, van twee kanten, onwennig als men was met deze nieuwe ervaring, maar tevens een leerzame. Temeer daar men voor dialoog in de openbaarheid koos.

Tegenwoordig komt men meer voorbeelden tegen van die open dialoog, vooral met de overheid. PIG's praten mee bij het TGV traject door 'het groene hart' en de

68. V an de Bunt, 1992.

69. Punch (1996).

70. van de Bunt (1992) noot 39.

71. Kimman (1991). 
Betuwe spoorlijn. In de wetgevingssfeer heeft de overheid nieuwe belangrijke instrumenten aangereikt zoals de W et O penbaarheid van Bestuur. Is hier de overheid bemiddelaar tussen belangengroepen en het bedrijfsleven, of is het een afleidingsmanoeuvre in een meer collusieachtig scenario?

Feit is in elk geval dat de risico's achter het vertrouwelijk overleg, achter het privatiseren van bestuurstaken, achter gedoog overeenkomsten en convenanten onderkend beginnen te raken, alleen ziet men het te weinig als een organisatiecriminologisch probleem.

\section{Remedies en onderzoek}

Hoe kan collusie voorkomen worden, hoe kunnen risico's verminderd worden en welke rol kan organisatiecriminologisch onderzoek daarbij spelen? Wat nu volgt is slechts een bescheiden illustratie van de diverse invalshoeken die zich aanbieden.

Eigenlijk zou men eerst naar de alternatieven moeten kijken, om pas daarna stil te staan bij de onderzoeksagenda, maar omwille van de tijd voeg ik die nu wat impressionistisch ineen, tot enkele voorbeelden.

- De klassiekste remedie indiceerde ik hierboven reeds: de koninglijke weg van de rechterlijke controle via de W et Openbaarheid van Bestuur. De rechter heeft als geen ander mogelijkheden om vermeende illegaliteiten boven tafel te krijgen, maar PIG's moeten de durf hebben om naar die rechter toe te stappen en die rechter moet zelf ook durven. W at Peters ${ }^{72}$ liet zien voor zeggenschapsrecht geldt ook voor het openbaarheidsrecht. Dat kan hard recht worden, als het instrument intensief gebruik wordt. Onderzoek kan de variaties in betekenis van dit instrument in kaart brengen.

- Wakend voor collusie, kan men stellen: de overheid dient zich zo controleerbaar mogelijk op te stellen, in elk geval meer dan de private sector. Hoe verhoudt zich dat streven met het steeds meer privatiseren van overheidstaken? Op zich zou men bij elke geprivatiseerde dienst onderzoek kunnen doen maar in het licht van de Vie d'Or casus $^{73}$ lijkt mij de verzekeringskamer een extra mooi voorbeeld. Daar ligt immers al veel materiaal over fouten uit het verleden en de maatschappelijke relevantie is groot. Zo' $n$ onderzoek zou tevens de specifieke verantwoordingsproblematiek van zelfstandige bestuursorganen naar de minister toe kunnen toelichten.

72. Peters (1979).

73. Intussen is er ook de A rdena casus, waarvan materiaal openbaar is. 
- Duidelijke leiding en open communicatie binnen de dienst kunnen veel problemen voorkomen, ook collusie ${ }^{74}$. M et name daarop gericht heeft Grabosky een intrigerende stelling ontwikkeld. De leiding van een publieke dienst moet niet alleen alert zijn op problemen bij contactambtenaren, men moet die vooronderstellen. Het niet hebben van problemen is in wezen verdachter. Niet ontdekte collusie lijkt erg op de ideale ambtenaar. Die heeft een uitstekend contact met zijn veld, weet alles en lost alles zelfstandig op ${ }^{75}$.

Deze stelling zou men kunnen toetsen bij bijvoorbeeld sectoren die erg exclusief van overheidsopdrachten afhankelijk zijn zoals de weg- en waterbouw.

- Zo belangrijk als collusiebewaking is, zo belangrijk is ook de zorg niet te overdrijven bij die collusiebewaking. Dat klinkt wellicht wat vreemd bij een fenomeen dat nog nauwelijks op de criminologische agenda staat, maar dat is wel een les die uit het corruptie-controle onderzoek te leren valt. Zoals strenge corruptiebewaking het risico in zich draagt van overkill, excessieve ineffectiviteit ${ }^{76}$, en nieuwe vormen van corruptie ${ }^{77}$ kan datzelfde gevaar spelen bij té strenge collusiebewaking. Dat betreft zowel proactieve als reactieve controlestructuren. De overheid kan onderhandelaars met het bedrijfsleven niet al te frequent wisselen, net zo min als dat men niet op elk schandaal een parlementaire enquête kan loslaten. $V$ ia de fictieve casusmethode zou men kunnen checken bij diensthoofden of politiek verantwoordelijken wanneer en hoe men zou ingrijpen.

- Collusieonderzoek zou men kunnen doen bij de ombudsman. Die heeft een eigen plaats in het Nederlandse bestel als waakhond tegen overheidscriminaliteit. Specifieke collusiegevoeligheid kan ik uit zijn jaarverslagen niet lezen, maar collusie is ook geen typisch klachtdelict. Het is een typische vorm van institutionele overheidsillegaliteit en die kan wel achter een individuele klacht schuilgaan. Dat de nationale ombudsman naast individuen ook organisaties kan aanklagen is in elk geval een groot goed, te meer, nu de Hoge Raad zo'n restrictief beleid voert inzake de strafrechtelijke vervolgbaarheid van overheidsorganen.

Een ander, en wellicht beter adres voor onderzoek naar collusiegevoeligheid met name binnen de ministeries is de $\mathrm{N}$ ationale Rekenkamer. Zij was de eerste die in haar rapport uit 1989 wees op het collusiegevaar en sindsdien is zij daar -

74. Wheeler en Rothman (1982).

75. Grabosky (1989).

76. A nechiarico en J acobs (1996).

77. N elken (1994). 
van alle overheidsinstanties - het meest alert op gebleven. Belangrijk is ook dat zij systematisch evalueert wat er met haar eigen onderzoeksresultaten gebeurt. $\mathrm{Zij}$ controleert altijd dubbel wat vooral op langere termijn een goed beeld kan geven van de collusierisico's bij de diverse ministeries.

Tot zover wat voorbeelden van mogelijk onderzoek, gekoppeld aan aspecten van preventiebeleid. Vaker - zo weten we van het corruptieonderzoek - zal het voorkomen dat men iets neutraals onderzoekt bij de overheid en daarbij ook rekening houdt met het collusiegevaar als zelfstandige categorie. Zo doet de vakgroep in $M$ aastricht onderzoek naar sancties in het mededingingsbeleid, en naar regelgeving en controle op de beurs, waarbij het collusiegevaar slechts een bijkomende factor is waar rekening mee gehouden wordt. Als er maar rekening mee wordt gehouden, daar ging het mij om vandaag.

\section{Besluit}

Ik heb vandaag collusie op de agenda gezet niet als theorie maar als categorie. Zoals corruptie een bijzondere categorie is bij individuele criminaliteit, is collusie een bijzondere categorie bij organisatiecriminaliteit. Het was niet benoemd, dat stelen door de overheid uit overheidsfondsen. Door dat wel te doen krijgen we een eerlijker beeld en een evenwichtiger discours.

Dan kunnen we komen tot bijstelling van selectieve criminaliteitsbeelden; tot een cultuur waarin daders toegeven dat er fouten zijn gemaakt en waarin schuld wordt genomen in plaats van à priori ontkend. Als een overheid daarin voorgaat heb je kans dat én organisaties én burgers dat voorbeeld wat vaker zullen volgen.

Ik denk niet dat door mijn pleidooi meer overheden vervolgd zullen worden. Dat was ook niet mijn bedoeling. Collusie loopt zelf vroeg of laat tegen haar eigen rechtsstatelijke en legitimiteitsgrenzen aan als ondemocratisch fenomeen.

W el denk ik dat, door het te benoemen - en via historische analyses te illustreren en te preciseren - men preventieve 'awareness' kan mobiliseren, in die zin dat overheden zich wapenen tegen een mogelijk collusieverwijt straks, bijvoorbeeld door vroegtijdig belangengroepen bij het vertrouwelijk overleg te laten. In feite gaat het om een meer controleerbare orde in een nu wel heel vrij veld.

Wijlen Steven Box typeerde criminologie als uiteindelijk het onderzoek naar mystificaties van macht ${ }^{78}$. Daar hoort de overvaller, tasjesrover en verkrachter onder, maar structureel mogen we falende bedrijven en overheden ook niet vergeten. $\mathrm{H}$ un

78. Box (1983). 
verleiding om samen boven de wet te gaan staan kan wezenlijk bedreigender voor een samenleving zijn ${ }^{79}$.

79. M et dank aan R. de Winter, A. Jettinghof en C. Flinterman voor hun kritisch commentaar. 
Mijnheer de Rector Magnificus, zeer gewaardeerde toehoorders

Aan het eind gekomen van deze rede wil ik graag enkele woorden van dank uitspreken.

Allereerst dank ik al diegenen die hebben bijgedragen aan de totstandkoming van deze leerstoel en aan het in mij gestelde vertrouwen. I $\mathrm{k}$ zal mijn best doen dit vertrouwen waardig te zijn

Waarde Mols, beste Gerard. De manier waarop jij met de vakgroep het strafrechtsonderwijs in Maastricht al vele jaren inricht, spreekt mij erg aan, mede vanwege het mensenrechtelijke - voor insiders U trechtse - accent, dat ruimte laat aan een criminologie die ook het gedrag van de overheid zelf problematiseert. Jij kon in jouw oratie professor Peters, ons beider mentor, nog bedanken. Nu hij overleden is doe ik het graag via jou. Jij zet zijn strafrechtelijke werk voort op jouw manier, maar met een zelfde gedrevenheid en engagement voor wat hij zo mooi omschreef als de precaire waarden waar recht voor staat. Ik hoop dat we nog lang samen kunnen werken.

Waarde De Batselier, beste Steven. Jij hebt mij vertrouwd gemaakt met de criminologie begin jaren zeventig in Leuven. Jouw bevlogenheid raakte velen, zo ook mij. Dat jouw lessen in vertrouwenspsychologie zouden leiden tot een levenslange vriendschap beschouw ik als een onvervangbaar goed.

Waarde Heyboer, beste Huib en waarde Hulsman, beste Louk. Jullie staan - zo verschillend als jullie zijn - voor het beste wat Limburg aan criminologie docenten heeft voortgebracht. Huib staat voor de praktische criminologie en Louk voor de radicale niet-straffen rechtstheorie. Ik dank jullie voor jullie bekommernis met de $M$ aastrichtse criminologie en voor jullie wijze vriendschap. Ik hoop van die wijsheid nog lang gebruik te mogen maken.

Waarde collegae criminologen. De criminologiegemeenschap wordt wel omschreven als klein maar fijn. In wezen is ze niet zo klein en is ze eerder streng en kritisch, ook op zichzelf, en zo hoort het. Ik vind het steeds weer uitdagend en prettig met jullie samen te mogen werken zowel binnen als buiten NVK verband.

Leden van de faculteit, leden van de vakgroep strafrecht en criminologie. Wetenschap is een manier van leven. Als ik zeg dat ik domweg gelukkig ben in deze Dapperstraat, dan weet $U$ wat ik daarmee bedoel. Ik geloof nog steeds in het Maastrichtse experiment, mede vanwege de hartelijkheid en familiale omgangsmoraal 
waarmee we samen die klus proberen zo goed mogelijk te klaren. En dat uiteraard zonder collusie!

Dames en heren studenten. I heb vandaag een vergeten hoofdstuk uit de organisatiecriminologie behandeld dat ik belangrijk acht. Het wil een specimen zijn van de criminologische bijdrage aan het juridische curriculum in de breedte. Het raakt naast strafrecht ook privaatrecht, bestuursrecht, sociaal- en internationaal recht. Aan de Universiteit Maastricht is door haar curriculumopbouw ruimte voor dit soort dwarsverband-denken. O ok methodisch is Maastricht bijzonder; dat vindt $u$ bij criminologie onder andere terug in de mogelijkheid tot eigen studentenonderzoek. Zo criminologie beoefenen met de studenten beleef ik steeds weer als een voorrecht, dat buitenstaanders moeilijk naar waarde kunnen schatten.

Tenslotte zijn jullie er, Minie en Frans, mijn private collusie. J ullie zijn me lief als geen ander, maar dat wisten jullie al; nu weet de rest het ook.

Ik dank U voor uw aandacht. 


\section{Literatuur}

A nechiarico, F. and Jacobs, J.B. (1996), The Pursuit of Absolute Integrety; how corruption control makes government ineffective, Chicago: The University of Chicago Press.

Ayres, I. (1987), 'How Cartels Punish: A structural theory of self-enforcing collusion' Columbia Law Review, pp. 295-325.

A yres, I. and Siegelman P. (1988), 'The economics of the insurance antitrust suits: Toward an exclusionary theory', Tulane Law Review, 63, pp. 971-997.

Ayres, I. and Braithwaite, J. (1992), Responsive Regulation; Transcending the Deregulation D ebate, New york: Oxford U niversity Press.

Bardach, E. and Kagan, R. (1982), Going by the Book: The problem of Regulatory U nreasonableness, Philadel phia: Temple U niversity Press.

Beenakkers, E.M.Th. en Grapendaal, M . (1995), Lekken en Lekkers, een verkennend onderzoek naar het lekken van vertrouwelijke informatie naar de pers, Den Haag: WODC.

Borghi, M . et M eyer-Bisch, P. (eds) (1995), La Corruption: L'envers des Droits de L'homme, Fribourg: Editions U niversitaires Friborg Suisse.

Bovens, M.A.P. (1990), Verantwoordelijkheid en Organisatie, Zwolle: Tjeenk Willink.

Box, S. (1989), Power, Crime and Mystification, London: Travistock.

Braithwaite, J. (1984), Corporate Crime in the Pharmaceutical Industry, London: Routledge and Kegan Paul.

Braithwaite, J. (1989), Crime, Shame and Reintegration, Cambridge: Canbridge University Press.

Braithwaite, J. and Pettit, Ph. (1990), Not J ust Deserts; A Republican Theory of Criminal J ustice, Oxford: Clarendon Press.

Brants, C.H. en Brants, K.L.K. (1991), De Sociale constructie van fraude, Arnhem: Gouda Quint.

Bunt van de, H.G. (1992), Organisatiecriminaliteit, Arnhem: Gouda Quint.

Bunt van de, H.G. (1993), 'M aatregelen tegen corruptie in het bedrijfsleven', J ustitiële Verkenningen, 19, pp. 35-50.

Clarke, M.J. (Ed) (1983), Corruption: Causes, Consequences and Control, London: Frances Pinter.

Clarke, M.J. (1990), Business Crime, its Nature and Control, Cambridge: Polity Press.

Clinard, M.B. and Y aeger, P.C. (1980), Corporate Crime, N ew Y ork: Free Press.

Coleman, J.W . (1982), The Asymmetric Society, N ew Y ork: Syracuse.

Coleman, J.W. (1985), The Criminal Elite: The Sociology of White Collar Crime, 
N ew Y ork: St. M artins Press.

Della Porta, D. (1996), 'A ctors in Corruption: Bussiness Politicians in Italy', International Social Science J ournal, Vol 48, nr. 3.

Dohmen, J. (1996), De Vriendenrepubliek, Nijmegen: SU N.

Douglas, J.D. and Johnson, J.M . (1977) Official Deviance: Readings in M alfeasance, misfeasance, and other forms of corruption, Philadelphia: Lippincott Company.

Duk, W. (1973) Tanden van het Recht, Zwolle: Tjeenk Willink.

Ermann, M .D. and Lundman, R.J. (Eds) (1996), Corporate Crime and Governmental Deviance (5th ed), New Y ork: Oxford U niversity Press.

Fisse, B. and Braithwaite, J. (1983), The impact of publicity on corporate offenders, A lbany: State U niversity of $\mathrm{N}$ ew $\mathrm{Y}$ ork Press.

Forster, E.M . (1951), Two Cheers for Democracy, Harmondsworth: Pinguin Books.

Frank, N. (1984), 'Policing Corporate Crime: A Typology of Enforcement styles', J ustice Quarterly, pp. 235-51.

Gamson, W.A. (1968), Power and D iscontent, Homewood: Dorsey Press.

Gamson, W.A . (1975), The Strategy of Social Protest, Homewood: D orsey Press.

Gladdish, K. (1991), Govering from the centre; politics and policy-making in the Netherlands, London: M acM illan.

Gottfredson, M . and Hirschi, T. (1990), A G eneral Theory of C rime, Stanford: Stanford U niversity Press.

Grabosky, P. and Braithwaite, J. (1986), Of manners gentle; enforcement strategies of Australian business regulatory agencies, Oxford: Oxford University Press.

Grabosky, P. (1989), Wayward Governance, Canberra: AIC.

Haan de, W. (1990), Politics of Redress, London: U nwin Hyman.

Heidenheimer, A.J., Johnston, M. and L evine, V.T. (Eds) (1989), Political Corruption: A Handbook, New brunswick: Transaction.

Heuvel van den, G (1993), Onderhandelen of Straffen: Over organisatie-criminaliteit en overheidscontrole, A rnhem: Gouda Quint.

Heuvel van den, G. (1994), 'G epolitiseerde bureaucratie en corruptie: Nigeria en Indonesië', in Bruinsma, $F$. e.a. (R ed.), Precaire Waarden, Liber Amicorum voor prof.mr. A.A.G. Peters, Arnhem: Gouda Quint.

Heuvel van den, G. (1994), 'Convenanten in de N ederlandse overlegeconomie', J ustitiële Verkenningen, 20, pp. 9-26.

Hibbeln, J.G. en V elema, W. (1993), Het WAO Debacle: De fatale missers van wettenmakers en uitvoerders, $U$ trecht: J an van A rkel.

Hoefnagels, G.P. (1981), Witte boordencriminaliteit, O pstellen over M isdaad en Macht, A ssen: V an Gorcum. 
H oekema, A . (1994) 'Onderhandelend Bestuur', Recht der Werkelijkheid, 1, pp. 97-114.

Huberts, L.W.J.C. (red.) (1992), Bestuurlijke corruptie en fraude in Nederland, Arnhem: Gouda Quint.

Huberts, L.W.J.C. (red) (1994), M achtsbederf Ter Discussie, A msterdam: V U Uitgeverij.

Huisman, W. en Niemeyer, E., m.m.v. Jansen M.V.C. en Braun, S.I.G. (1998), Organisatiecriminaliteit in Nederland, een eerste verkenning. (verschijnt binnenkort)

Hulsman, L.H.C. (1965), Handhaving van Recht, Deventer: Kluwer.

Kagan, R.A . (1978), Regulatory J ustice, N ew Y ork: Russel Sage.

Kagan, R.A . and Scholz, J.T. (1984), 'The Criminology of the Cooperation and Regulatory Enforcement Strategies' in Hawkins, K. and Thomas, J.M. (Eds), Enforcing Regulations, Boston: Kluwer Nijhoff.

Kagan, R.A. (1990), 'How much does $L$ aw matter? Labor Law, Competition and Waterfront Labor Relations in Rotterdam and the U.S. Ports', Law and Society Review, 24, pp. 61-84.

Kleiman, W.M. en van den Berg, E.A.I.M. m.m.v. van der Linden, E.J.A. (1995), Overtredende Overheden; vervolgingsbeleid inzake milieudelicten, 's Gravenhage: WODC.

Levi, M. (1991), 'Regulating M oney Laundering: The Death of Bank Secrecy in the UK.' The Britisch J ournal of Criminology, 31, pp. 109-25.

Lijphart, A . (1968), The Politics of Accommodation, Berkeley: U niversity of California Press.

M cBarnet, D. (1991), 'W hiter than W hite Collar Crime: Tax, Fraud Insurance and the M anagement of Stigma', Britisch Journal of Sociology, 42, pp. 323344.

M itchell, R. (1996), Political Bribery in J apan, Honolulu: University of Hawaii Press.

Mulder, A . (1950), De handhaving der sociaal-economische wetgeving, Den $\mathrm{H}$ aag.

M ulder, M . (1977), O mgaan met Macht, A msterdam: Elsevier.

Nelken, D. (Ed) (1994), White Collar Crime, A ldershot: Dartmouth.

N elken, D. (1994), 'W hom can you trust? The future of Comparative Criminology' in $D$. N elden ( $E d)$, The Futures of C riminology, L ondon: Sage.

N elken, D. (1996), 'The J udges and political corruption in Italy', J ournal of Law and Society, 23, pp. 95-113.

Nelken, D. and Levi, M. (1996), 'The Corruption of Politics and the Politics of Corruption: An Overview', J ournal of Law and Society, 23, pp. 1-18.

N oordegraaf, M., Ringeling, A.B. en Zwetsloot, F.J.M . (red) (1995), De ambte- 
naar als publiek ondernemer, Bussum: Dick Coutinho.

Ong A Swie, S.R. (1995), 'De Rol van de Fiscale Boete bij Belastingcontrole en Fraudebestrijding' in Lint, van, A.J. e.a. (red): Fiscale Boetes, A rnhem: Gouda Quint.

Passas, N. and N elken. D. (1993), 'The thin line between legitimate and criminal enterprises: subsidy frauds in the European Community', Crime, Law and Social Change, 19, pp. 223-243.

Pearce, F. and Snider, L. (Eds) (1995), Corporate Crime: Contemporary D ebates, Toronto: U niversity of Toronto Press.

Peters, A.A.G. (1979), 'Recht als project', Ars Aequi, 28, pp. 881-893.

Pizzorno, A. en Della porta, D. (1994), De rol van zakenpolitici in de Italiaanse politiek, Nederlands J uristenblad, pp. 1563-1574.

Punch, M . (1996), Dirty Business; Exploring Corporate Misconduct, London: Sage Publ.

Queloz, N. (1996), 'Crise des Valeurs et Processus de Corruption: au-delà

Stratégie Pénale', Revue International de Criminologie en de Police Technique, Vol. 49, July/Septembre.

Reisman, W.M . (1979), Folded Lies, New Y ork: Free Press.

Rose - A ckerman, S. (1996), 'D emocracy and 'Grand' Corruption', International Social Science J ournal, vol 48, nr. 3.

Ross, E.A. (1907), Sinn and Society; An Analysis of Latter Day Society, Boston: Houghton M ifflin.

Ruimschotel, D. (1993), Corruptie en Fraude in Nederland, A rnhem: Gouda Quint.

Ruimschotel, D. (1996), 'Corruptie als combinatie van irreguliere bevoordeling en infaam verraad', Nederlands J uristenblad, pp. 1554-1562.

Shapiro, S.P. (1990), 'Collaring the Crime, $N$ ot the Criminal: Reconsidering the Concept of White Collar Crime', The American Sociological Review, 55, pp. 346-365.

Stanley, Chr. (1992), 'Serious M oney: Legitimation of deviancy in the Financial M arkets', International J ournal of Sociology of Law, 28, pp. 43-60.

Steffensmeier, D. (1989), 'On the Causes of 'W hite Collar' Crime: An A ssessment of Hirshi and Goffredson's Claims', Criminology, 27, pp. 345-358.

Stout, H.D. en Hoekema, A.J. (red) (1994), O nderhandelend Bestuur. Zwolle: Tjeenk Willink.

Sutherland, E.H. (1983), White Collar Crime; The Uncut Version, New Haven: $Y$ ale U niversity Press.

Swaaningen van, R. (1997), Critical Criminology, London: Sage.

Tonry, M. and Reiss, A.J. jr. (eds) (1993), Beyond the Law: Crime in Complex Organisations, Chicago: University of Chicago Press.

Tutt, N. (1989), Europe on the Fiddle; the Common Market Scandal, London: 
Helm.

Tuurenhout, M .E. (1992), Parlementaire Controle en Ambtelijke verantwoordelijkheid, A rnhem: Gouda Quint.

V ahlenkamp W. und Knauss, I. (1995), Korruption: ein unscharfes $P$ hänomen als Gegenstand zielgerichteter Prävention, W iesbaden: Bundeskriminalamt.

Vervaele, J.A.E., Ruimschotel, D. en Widdershoven, R. (1990), Rechtshandhaving bij visquotering, U trecht: NISER en AGB.

Vervaele, J.A.E. (1994), Handen en tanden van het (gemeenschaps)recht, D eventer: Kluwer.

Vugt van, G.W.M. en Boet, J.F. (1994), Zuiver handelen in een vuile context, Arnhem: Gouda Quint.

Walster, E., W alster, G.W . and Berscheid, E. (1978), Equity, Theory and Research, Boston: Allyn and Bacon.

W assenberg, A.F.P. (1980), ' $\mathrm{N}$ eo corporatisme: de carrière en de schutskleuren van een begrip' in: Verhallen H.J. (red), Belangengroepen en Democratie, Alphen a/d Rijn: Samson.

W assenberg, A.F.P. (1987), 'K unnen organisaties el kaar vertrouw en? O ef eningen in horizontaal bestuur', Recht der Werkelijkheid, 2, pp. 106-132.

W eisburd, D., Wheeler, S., Waring, E. and Bode, N. (1991), Crimes of the Middle Classes: White-Collar Offenders in the Federal Courts, $\mathrm{New}$ Haven: $Y$ ale U niversity Press.

Wolferen, van K.G. (1989), The Enigma of Japanese Power, London: MacMillan.

Woodall, Br. (1966), J apan under Construction: Corruption, Politics and Public Works, Berkeley: University of Berkeley Press. 